\title{
Protein analysis in dissolved organic matter: What proteins from organic debris, soil leachate and surface water can tell us - a perspective
}

\author{
W. X. Schulze \\ Center for Experimental Bioinformatics, University of Southern Denmark, Campusvej 55, 5230 Odense, Denmark
}

Received: 15 November 2004 - Published in Biogeosciences Discussions: 20 December 2004

Revised: 21 February 2005 - Accepted: 1 March 2005 - Published: 4 March 2005

\begin{abstract}
Mass spectrometry based analysis of proteins is widely used to study cellular processes in model organisms. However, it has not yet routinely been applied in environmental research. Based on observations that protein can readily be detected as a component of dissolved organic matter (DOM), this article gives an example about the possible use of protein analysis in ecology and environmental sciences focusing on different terrestrial ecosystems. At this stage, there are two areas of interest: (1) the identification of phylogenetic groups contributing to the environmental protein pool, and (2) identification of the organismic origin of specific enzymes that are important for ecosystem processes. In this paper, mass spectrometric protein analysis was applied to identify proteins from decomposing plant material and DOM of soil leachates and surface water samples derived from different environments. It is concluded, that mass spectrometric protein analysis is capable of distinguishing phylogenetic origin of proteins from litter protein extracts, leachates of different soil horizons, and from various sources of terrestrial surface water. Current limitation is imposed by the limited knowledge of complete genomes of soil organisms. The protein analysis allows to relate protein presence to biogeochemical processes, and to identify the source organisms for specific active enzymes. Further applications, such as in pollution research are conceivable. In summary, the analysis of proteins opens a new area of research between the fields of microbiology and biogeochemistry.
\end{abstract}

\section{Introduction}

Dissolved organic matter (DOM) plays an important role in the carbon biogeochemistry coupling terrestrial and aquatic carbon pools. These pools of dissolved organic nitrogen

Correspondence to: W. X. Schulze

(waltraud@bmb.sdu.dk) and carbon are significant for $\mathrm{C}$ and $\mathrm{N}$ cycles of terrestrial ecosystems and undergo variations in season and depth profile. The composition and origin of DOM may depend on the organisms living in a given environment (Michalzik and Matzner, 1999; Kaiser et al., 2001). Dissolved organic matter has so far been well studied with respect to their $\delta^{13} \mathrm{C}$ and $\delta^{15} \mathrm{~N}$ origin and their basic chemical structure (Michalzik and Matzner, 1999; Gleixner et al., 2001; Kaiser et al., 2001). ${ }^{15}$ N NMR analysis has demonstrated that a significant amount of nitrogen is present in amide form (Almendros et al., 1991), and thus possibly as protein. Recent NRM analyses of DOM in wetlands indicate that protein-like components are produced in situ and can contribute up to $30 \%$ in total DOM (Lu et al., 2003). Characterization of different molecular weight fractions of dissolved organic matter using fluorescence detections also clearly indicate the presence of proteins (Her et al., 2003). However, not much is actually known about this protein component of DOM. Analysis of these proteins, i.e. characterization of their identity, their phylogenetic origin, their functions, and spatial distribution could link ecosystem biology to biogeochemical processes. The analysis of proteins in environmental samples so far has mainly been pursued in marine biology involving the detection of specific proteins by immunological techniques, and $\mathrm{N}$-terminal sequencing of isolated proteins (Keil and Kirchman, 1993; Tanoue, 1996; Tanoue et al., 1996; Suzuki et al., 1997; Yamada and Tanoue, 2003). Molecular fluoroscopy and chemical analysis has identified amino acids and protein traces also in lake sediment (Wu and Tanoue, 2002; Wu et al., 2003), suggesting that protein indeed is a significant proportion also of terrestrial DOM. However, the protein from terrestrial sources of DOM so far have not been considered for in-depth analyses.

Protein mass spectrometry is one of the fastest developing research areas, and contributes substantially to our understanding of organisms at the cellular level (Aebersold and Mann, 2003; Tyers and Mann, 2003). Recently there

(C) 2005 Author(s). This work is licensed under a Creative Commons License. 
Table 1. Summary of the samples analyzed in this study, nitrate concentrations are given as a measure of microbial activity. ${ }^{\text {a }}$ Samples for Figs. 2 and 3, ${ }^{\mathrm{b}}$ samples for Fig. 5, ${ }^{\mathrm{c}}$ samples for Fig. 6, ${ }^{\mathrm{d}}$ samples for Fig. 7, n.d.: no measurements.

\begin{tabular}{|c|c|c|c|c|c|c|c|}
\hline & $\begin{array}{l}\text { dissolved } \\
\text { organic } \\
\text { carbon } \\
\left(\mathrm{mg} \mathrm{L}^{-1}\right)\end{array}$ & $\begin{array}{l}\text { total } \\
\text { carbon } \\
\left(\mathrm{mg} \mathrm{g}^{-1}\right)\end{array}$ & $\begin{array}{l}\mathbf{N O}_{3}^{-} \\
\left(\mathrm{mg} \mathrm{L}^{-1}\right)\end{array}$ & $\begin{array}{l}\text { climatic } \\
\text { region }\end{array}$ & $\begin{array}{l}\text { sampling } \\
\text { season } \\
\text { (month) }\end{array}$ & $\begin{array}{l}\text { sampling } \\
\text { depth } \\
(\mathrm{cm})\end{array}$ & soil type \\
\hline \multicolumn{8}{|c|}{ surface water samples } \\
\hline rain water ${ }^{b}$ & $1.7 \pm 0.5$ & & & temperate & November & surface & \\
\hline peat bog lake ${ }^{b}$ & 30.1 & & & temperate & June & surface & \\
\hline acidic creek $^{\mathrm{b}}$ & n.d. & & & temperate & November & surface & \\
\hline stream low $b, d$ & 16.9 & & & arctic & August & surface & \\
\hline stream high $^{\mathrm{b}, \mathrm{d}}$ & 23.3 & & & arctic & July & surface & \\
\hline snowmelt ${ }^{b, d}$ & 17.8 & & & arctic & May & surface & \\
\hline \multicolumn{8}{|c|}{ soil leachate samples } \\
\hline beech forest ${ }^{a, c}$ & $20.2 \pm 5.8$ & 75 & 14.5 & temperate & July & 5 & cambisol \\
\hline beech forest ${ }^{a}$ & 17.5 & 13 & 2.8 & temperate & January & 5 & cambisol \\
\hline beech forest ${ }^{\mathrm{a}}$ & $8.2 \pm 2.7$ & 63 & 0.5 & temperate & July & 90 & cambisol \\
\hline beech forest ${ }^{\mathrm{a}}$ & 7.3 & 10 & 0.5 & temperate & January & 90 & cambisol \\
\hline spruce forest ${ }^{\mathrm{c}}$ & $25.2 \pm 6.0$ & 48 & 4.4 & temperate & April & 5 & dystric cambisol \\
\hline pine forest ${ }^{c}$ & $39.2 \pm 9.8$ & 377 & n.d. & temperate & July & 5 & arenosol \\
\hline sphagnum bog ${ }^{c}$ & n.d. & n.d. & 0.8 & temperate & November & 50 & histosol \\
\hline larch forest $\mathrm{N}^{\mathrm{c}}$ & $40.1 \pm 2.9$ & n.d. & n.d. & arctic & August & 5 & gelic podzol \\
\hline larch forest $S^{d}$ & $55.4 \pm 3.4$ & n.d. & n.d. & arctic & August & 5 & gelic podzol \\
\hline larch forest $\mathrm{N}^{\mathrm{d}}$ & 16 & n.d. & n.d. & arctic & August & $\begin{array}{l}40, \\
\text { above } \\
\text { permafrost }\end{array}$ & gelic podzol \\
\hline
\end{tabular}

have been considerable efforts to extend genomic and proteomic analyses beyond the boundary of organisms. These approaches were termed meta-genomics or meta-proteomics. They involve isolation and sequencing of random DNA samples extracted from environments, such as oceans and soil (Tyson et al., 2004; Venter et al., 2004), as well as characterizations of proteins from bacterial communities in waste water sludges (Wilmes and Bond, 2004). In contrast to DNA and RNA, proteins combine information about the taxonomy of the active pool of organisms with a catalytic function. By directly analyzing the protein component of organic matter, we can conclude about the identity of the organisms contributing to the DOM pool, and at the same time also understand the functional contribution of certain proteins to biogeochemical processes. In a pioneer study, the protein composition of DOM from different soil layers and from organic soil particles was analyzed. There it was shown that a large number of proteins is present in soil leachates, and that they can mirror the phylogenetic groups present in ecosystems. Thus, the approach has been referred to as "proteomic fingerprinting" (Schulze et al., 2005).

By further pursuing the analysis of "proteomic fingerprints", this paper presents taxonomic and functional information of the protein component of DOM from contrasting environmental sources. The paper focuses on (i) analysis of organisms contributing to decomposition of plant material, (ii) a comparison of taxonomic units present in different surface waters, and (iii) comparison of taxonomic units in DOM from leachates of different soil types. Furthermore, functional information was exploited by classifying identified proteins according to (iv) size and (v) cellular function. It is concluded that routine analysis of proteins from DOM 


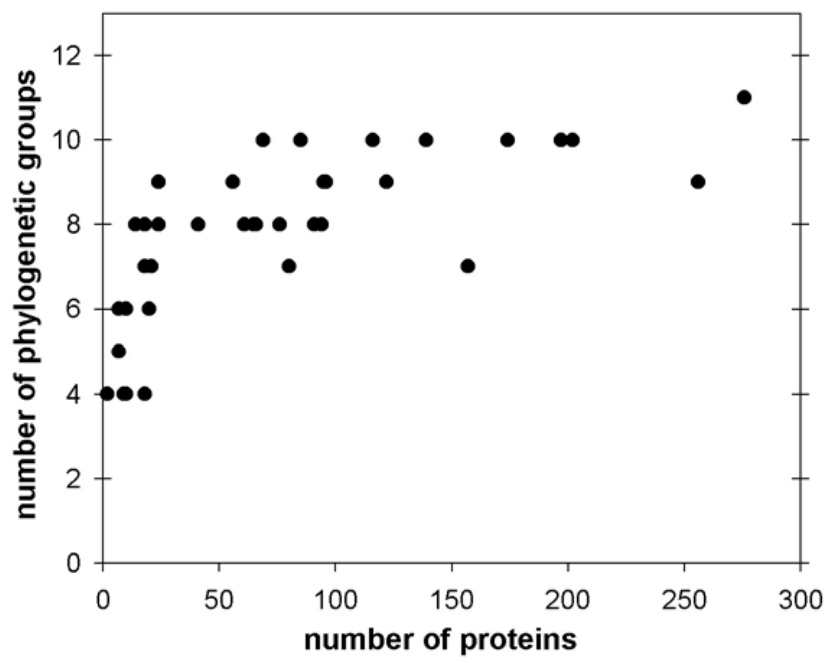

Fig. 1. The number of phylogenetic groups distinguished and the number of total proteins identified for each sample analyzed. The number of phylogenetic groups distinguished does not depend on the number of proteins identified.

has the potential to develop into a novel field of ecological and environmental research.

\section{Methods}

\subsection{Sampling sites}

In order to validate the "proteomic fingerprint" method of taxonomic and functional classification, sampling sites were chosen from arctic and temperate regions comprising different soil types and surface waters.

\subsubsection{Organic matter decomposition samples}

Proteins were extracted from three independent samples collected from four different stages of organic matter decomposition on a permafrost soil near Tura, Central Siberia. The sampling site was of pale-yellow soils with vegetation dominated by feather mosses. Along a soil depth profile an area of $10 \times 10 \mathrm{~cm}$ was sampled. Vegetation was separated into green and brown parts, and material from litter horizon and FH horizon was subsequently processed as described in Sect. 2.2. From this sampling site in Siberia, also soil leachate and stream water was collected. All surface water and soil leachate samples are summarized in Table 1.

\subsubsection{Surface water sources}

Filtered and freeze-dried samples from different terrestrial surface water sources were analyzed: (i) Lake Hohloh is a brown water peat pond $(\mathrm{pH} 3.4)$ in a natural preservation area at the top of a mountain (1000 m above sea level) in the Black
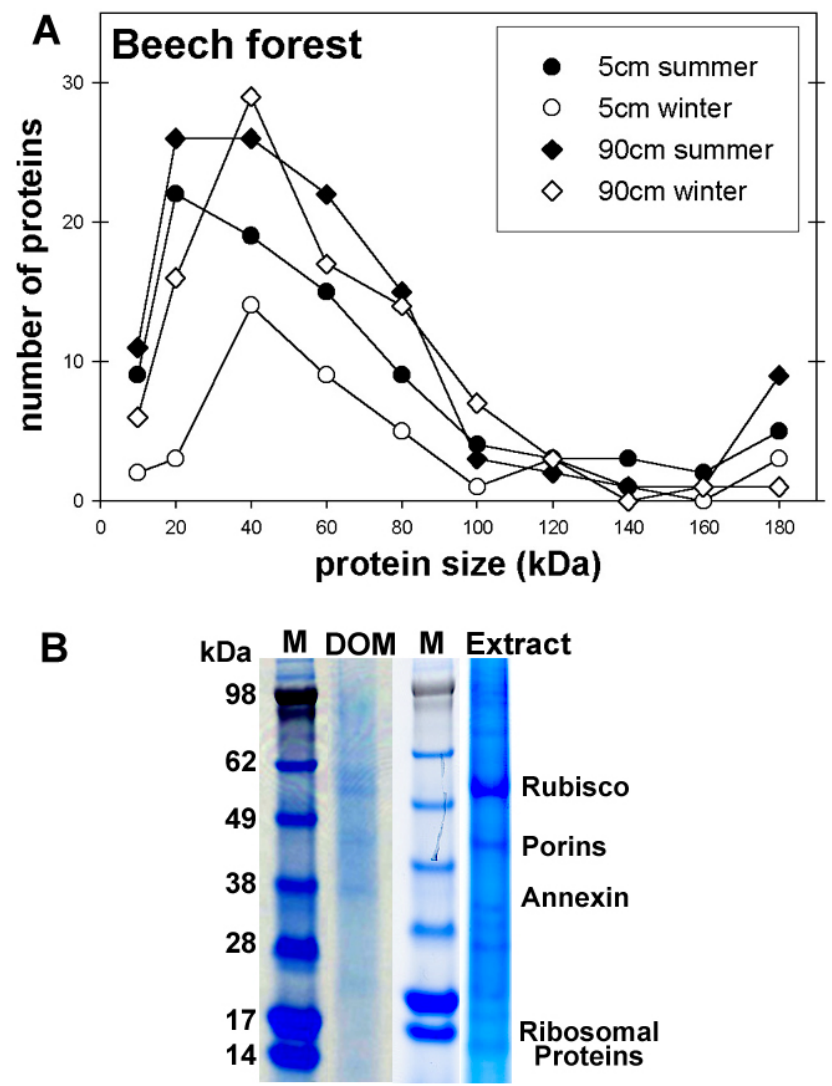

Fig. 2. Size distribution of identified proteins from DOM leachates of a beech forest on rendzic leptosol. (A) Size distributions are shown for proteins from DOM samples two different soil depths $(5 \mathrm{~cm}$ and $90 \mathrm{~cm})$ and seasons (summer and winter). Proteins from all organisms were included in the size distribution. (B) SDS gradient gel (12\%-4\%) of a typical DOM sample and an extract from decomposing plant material. Typical proteins identified are indicated at their approximate position in the gel. The lanes in the gel are as follows: M, Molecular weight marker; DOM, dissolved organic matter of a beech forest soil leachate; Extract, protein extract from dried brown plant material.

Forest, Germany. The lake is only recharged by precipitation and the water level is controlled by natural outflow. The mean dissolved organic carbon (DOC) of the lake water was $25.6 \pm 3.2 \mathrm{mg} \mathrm{L}^{-1}$ (Kracht and Gleixner, 2000). (ii) An acidic creek was sampled at the Waldstein, site Köherloh, Germany. It is a drainage creek to a peatland with organic substrate of 30 to $40 \mathrm{~cm}$ thickness. (iii) a stream was sampled in a watershed located on the western edge of a continuous permafrost distribution near Tura, Central Siberia $\left(64^{\circ} 15^{\prime} \mathrm{N}, 100^{\circ} 13^{\prime} \mathrm{E}\right)$. Two samples were obtained, one during early summer baseflow ("low water") and one during a midsummer stormflow ("high water"). (iv) snow melt run-off was collected at the Tura site, Central Siberia (v) rain water collected in dark rain collectors at $1 \mathrm{~m}$ above ground at the Waldstein, site Coulissenhieb, Germany. 


\subsubsection{Soil leachates}

DOM of leachates at $5 \mathrm{~cm}$ depth from different soil types from temperate and arctic regions were investigated: (i) Leachate from a cambisol was taken form the unmanaged beech forest of the National Park Hainich, Germany, at $430 \mathrm{~m}$ elevation. At the sampling site, samples were taken of the 5 to $10 \mathrm{~cm}$ horizon as well as in $90 \mathrm{~cm}$ depth. One sample was taken in summer (July) and one in winter (January). Soil humus was of mull type. (ii) Leachate from haplic podzol was taken from the Waldstein, site Coulissenhieb, Germany, a managed spruce forest growing at an elevation of $750 \mathrm{~m}$. The organic layer was of mor type. (iii) A sample from arenosol was obtained from a 160 year-old Pinus sylvestris forest near Seybothenreuth, Germany at $490 \mathrm{~m}$ above sea level. Total soil carbon concentration was $377 \mathrm{mg} \mathrm{g}^{-1}$, and organic floor layer was of mor type. (iv) Leachate from a histosol was sampled, from a Sphagnum bog with Betula at the Waldstein, site Köhlerloh, Germany and (v) leachate form gelic podzol was obtained from a Siberian larch forest at a north and south facing slope directly below the organic layer $(5 \mathrm{~cm})$ and just above permafrost $(40 \mathrm{~cm})$. Soil humus was of mor type. Equal amounts $(10 \mathrm{mg})$ of freeze-dried DOM were analyzed as described in Sect. 2.2.

Except for the extracts from decomposing plant material, the methods described here focus on the analysis of free proteins in organism-free dissolved organic matter. Protein contents are very low, thus pre-concentration of the samples is necessary. Surface water samples were collected, filtered through $0.2 \mu \mathrm{m}$, and freeze-dried. Percolating soil water leachate was obtained using glass ceramic suction plates. Plates were installed at $5 \mathrm{~cm}$ soil depth. Water was collected every fortnight and filtered through a $0.2 \mu \mathrm{m}$ acetate filter prior to freeze-drying. Prior to analysis, samples were rehydrated using $500 \mu \mathrm{L}$ of $50 \mathrm{mM}$ Tris- $\mathrm{HCl}, \mathrm{pH} 8$.

\subsection{Protein extraction from material of decomposition line}

Plant material and detritus was dried and pulverized. Equal amounts $(20 \mathrm{mg})$ of powder was extracted using $500 \mu \mathrm{L}$ of $50 \mathrm{mM}$ Tris- $\mathrm{HCl}, \mathrm{pH} 8,150 \mathrm{mM} \mathrm{NaCl}, 1 \%$ Nonident P-40 under heavy mixing for $10 \mathrm{~min}$. Extracts were then processed as described in Sect. 2.4. These protein extracts represent the protein composition before adsorption to soil particles and thus are not directly comparable to the protein composition of organism-free soil leachates.

\subsection{Sample preparation and analysis by LC-MS}

Humic acids, phenolic compounds, and other small molecules were removed from the DOM solution by gel filtration over Sepharose 4B, fractions were collected up to a molecule size of $4 \mathrm{kDa}$. Protein containing fractions were combined, protein was concentrated by ethanol precipitation. Proteins from extracts of decomposing plant material were separated via SDS-polyacrylamide gel electrophoresis. After staining with colloidal coomassie, each lane was cut into slices of approximately equal protein content and proteins in the slices were in-gel digested using trypsin (Shevchenko et al., 1996). DOM samples were directly digested in-solution after resuspending pelleted proteins in $6 \mathrm{M}$ urea and $2 \mathrm{M}$ thiourea. Prior to trypsin digestion, proteins were denatured with $1 \mu \mathrm{g}$ DTT per $50 \mu \mathrm{g}$ protein and sulfhydryl groups were modified using iodoacetamide ( $5 \mu \mathrm{g}$ per $50 \mu \mathrm{g}$ protein). The trypsin digest was then performed by adding four volumes of $50 \mathrm{mM} \mathrm{NH} \mathrm{NHCO}_{3}$ buffer and trypsin to a final concentration of $1 \mu \mathrm{g}$ per $50 \mu \mathrm{g}$ protein. In all cases, tryptic peptides were extracted from the gel particles with acetonitrile, and desalted using C18-based STAGE-tips (Rappsilber et al., 2003).

Mixtures of tryptic peptides were separated by nanoflow liquid chromatography (Ishihama et al., 2002) prior to analysis by high mass-accuracy tandem mass spectrometry (LC MS/MS) on a QSTAR pulsar quadrupole time-of-flight hybrid mass spectrometer. Sequences of tryptic peptides were derived by information-dependent acquisition of fragmentation spectra of multiple-charged peptides (Rappsilber et al., 2002). Acquired spectra were searched against the NCBI protein database (http://www.ncbi.nlm.nih.gov/) using the Mascot search algorithm (Perkins et al., 1999). The following search parameters were applied: maximum of one missed trypsin cleavage, cysteine carbamidomethylation, methionine oxidation, and a maximum $0.2 \mathrm{Da}$ error tolerance in both the MS and MS/MS data (40 ppm after dynamic recalibration). Only fully tryptic peptides were considered and all sequences were manually verified against the raw mass spectrometric data using accepted rules for peptide fragmentation in a quadrupole-TOF hybrid mass spectrometer (Roepstorff and Fohlman, 1984). On average, 30\% of the proteins were identified by a single tryptic peptide, to all other proteins more than one tryptic peptide was found.

\subsection{Taxonomic and functional classification}

The protein sequence derived from MS/MS spectra of tryptic peptides bears taxonomic information of the organism of origin. In most cases in this study, the sequences obtained from tryptic peptides were unique to a specific group of organisms or even single species (Shevchenko et al., 2001; Rappsilber and Mann, 2002). Since full sequence information is available only for a limited number of organisms, the identified proteins were grouped according to broader taxonomic levels following the nomenclature of the NCBI taxonomy browser (http://www.ncbi.nlm.nih.gov/ Taxonomy/taxonomyhome.html/). Especially for bacteria, vast genomic information is available which readily allows to distinguish finer categories. This was carried out in one example. For the aim of this study, it is not necessary to recover a full proteome for any organism, rather it is sufficient to recover one protein per organism that contains species 
specific information. Information about protein size for all identified proteins was obtained from the NCBI database (http://www.ncbi.nlm.nih.gov).

For taxonomic classification, proteins originating from bacteria, archaea, and viruses were not separated into further subgroups. Proteins from eukaryotes were sorted by their origin from green plants, metazoa, fungi, and "unicellular eukaryota" containing all those taxa that do not belong to the three major groups of eukaryota. Proteins from plants were further grouped into "algae" and "vascular plants". Proteins from metazoans were classified into platyhelminthes, protostomia (annelid worms, insects, and mollusks), nematoda, and vertebrata (mammals, birds, reptiles amphibians, fish). In some cases, tryptic peptides identified regions of proteins which are highly conserved among organisms from different taxonomic groups. These proteins were designated as "not classified". Protein sequences were analyzed for redundancy by pairwise alignment of all identified protein sequences. Sequences with an identity greater than $95 \%$ were considered identical. The functional attributes of the identified proteins were assigned following the Enzyme Commission Classification Scheme (see Fig. 3).

\subsection{Statistical analysis}

Taxonomic protein distributions were compared using a ChiSquared test. The taxonomic distribution of protein entries in the NCBI database were used as a reference.

Hierarchical clustering was achieved by correlation-based grouping using the dChip software (http://www.dchip.org/). Different sampling sites were grouped according to the relative abundance of different taxonomic groups.

\section{Results}

\subsection{Phylogenetic groups and protein amount}

The "proteomic fingerprint" is based on the classification of proteins into their taxonomic groups of origin. In the present study, only 12 different taxonomic categories were distinguished (see Sect. 2.5). In samples with 20 or more proteins identified the number of distinguished taxonomic groups ranged from six to ten independent of protein number (Fig. 1). Only in one case, all 12 distinguished taxonomic units were recognized. The taxonomic classification taken here is rather broad, as the genomic sequence information available in databases is still limiting.

\subsection{Protein size distribution and protein function}

The size distribution of proteins identified from DOM of soil leachates of a European beech forest (see Table 1) peaks at about $40 \mathrm{kDa}$ (Fig. 2A) and was independent of soil depth and season. The size distribution found here is in agreement with calculated average protein sizes for $E$. coli of $35 \mathrm{kDa}$

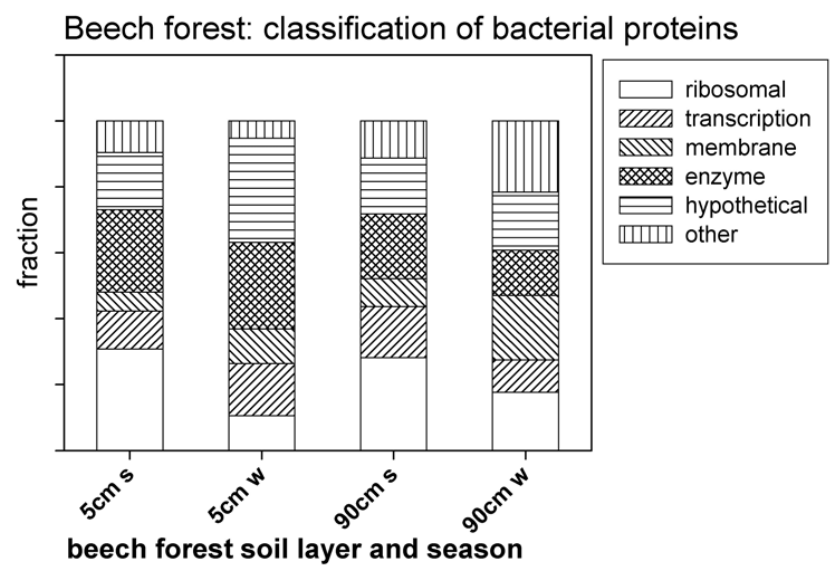

Fig. 3. Functional classification of the bacterial proteins identified from leachates of a beech forest on rendzic leptosol for two different soil depths $(5 \mathrm{~cm}$ and $90 \mathrm{~cm})$ and seasons (summer and winter).

and $51.8 \mathrm{kDa}$ for human (Cagney et al., 2003). The size distribution also corresponds with the most prominent bands on a SDS-Gel being visible between 68 and $25 \mathrm{kDa}$. In samples from decomposing plant material, Rubisco is the dominant protein, while DOC samples contain ribosomal proteins, membrane porins or cytoskeletal proteins as distinct bands besides a much weaker band of Rubisco (Fig. 2B).

Bacterial proteins identified from DOM of a beech forest leachate (see Table 1) in this study were classified according to their cellular function. Most proteins identified were ribosomal proteins, followed by an additional large group of metabolic enzymes (Fig. 3). The apparent changes in the abundance of ribosomal proteins that can be observed between DOM samples from summer and winter cannot readily be explained and needs further investigation. It can be speculated that the ribosomal proteins may indicate differences in bacterial activity.

Protein synthesis (i.e. ribosomes) and energy metabolism (i.e. metabolic enzymes) are also the two most abundant categories of protein function in living organisms (The Arabidopsis Genome Initiative, 2000), indicating that the DOM protein analysis indeed reflects the protein composition of cells from contributing organisms. Among the bacterial membrane proteins identified in this study, porin, subunits of $A B C$ type branched chain amino acid transport systems, and subunits of the ATP-synthase were the most common. This is in agreement with recent immunochemical studies of dissolved proteins in ocean waters (Yamada and Tanoue, 2003) and a two-dimensional gel electrophoresis/MALDI-TOF analysis of bacterial communities on activated waste water sludge (Wilmes and Bond, 2004). In both studies, also porins were identified as the most abundant membrane proteins. 


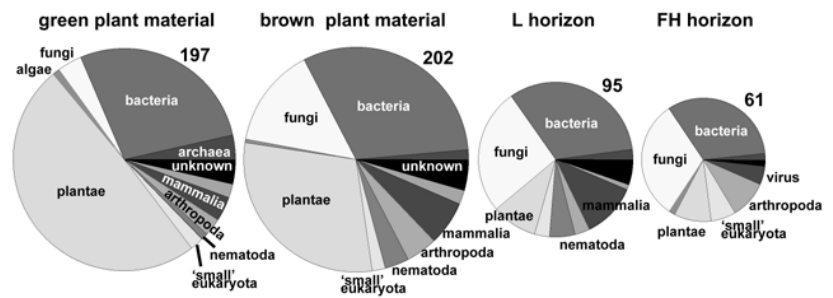

Fig. 4. Phylogenetic distribution of proteins extracted from decomposing plant material at different layers ranging from a green moss layer to the FH horizon. Areas of the pie charts represent the number of proteins identified. Numbers of proteins identified are stated next to the pie charts, which are drawn in proportional size to the number of proteins.

3.3 Analysis of organisms contributing to decomposition of plant material

Proteins were extracted from four different stages of organic matter decomposition, such as green plant material, brown plant material, litter horizon (LH), and fermentation horizon (FH). As expected, plant proteins were found to make up the largest fraction in extracts from green layers, but the second largest fraction of proteins is bacterial proteins (Fig. 4). Among the plant proteins, a high number of proteins specific to mosses were identified, such as moss-specific isoforms of RubisCO, ATP-synthase, and glyceraldehyde-3-phosphatedehydrogenase (data not shown).

The fraction of plant proteins decreased with decomposition, while the fraction of fungal proteins increased in deeper litter layers. In the $\mathrm{L}$ and $\mathrm{FH}$ horizons, fungi and bacteria were the dominating taxonomic origins of proteins. Among the fungal proteins, proteins from basidiomycetes were only detected in the $\mathrm{L}$ and FH layers, while the vast majority of fungal proteins was from ascomycetes. With increasing decomposition, the total number of identified proteins decreases and drops to $30 \%$ in the FH horizon compared to the total number of proteins identified in the green moss layer.

\subsection{Protein origin in surface waters}

Firstly, rain water contained only very few proteins originating from bacteria and viruses. However, different surface water samples show a vast diversity of protein origin (Fig. 5). A peat bog lake was dominated by bacterial proteins, with only $22 \%$ of proteins originating from other organisms, mainly viruses, vertebrates, and protostomia. In total, proteins from seven phylogenetic groups were distinguished.

An acidic creek flowing through a bog also showed a high fraction of bacterial proteins. In contrast, the pattern of protein origin and protein amount of a small stream in the forest tundra of Siberia was dependent on water flow levels. At low baseflow, only small amount of protein was detected, and these originated only from four different phylogenetic
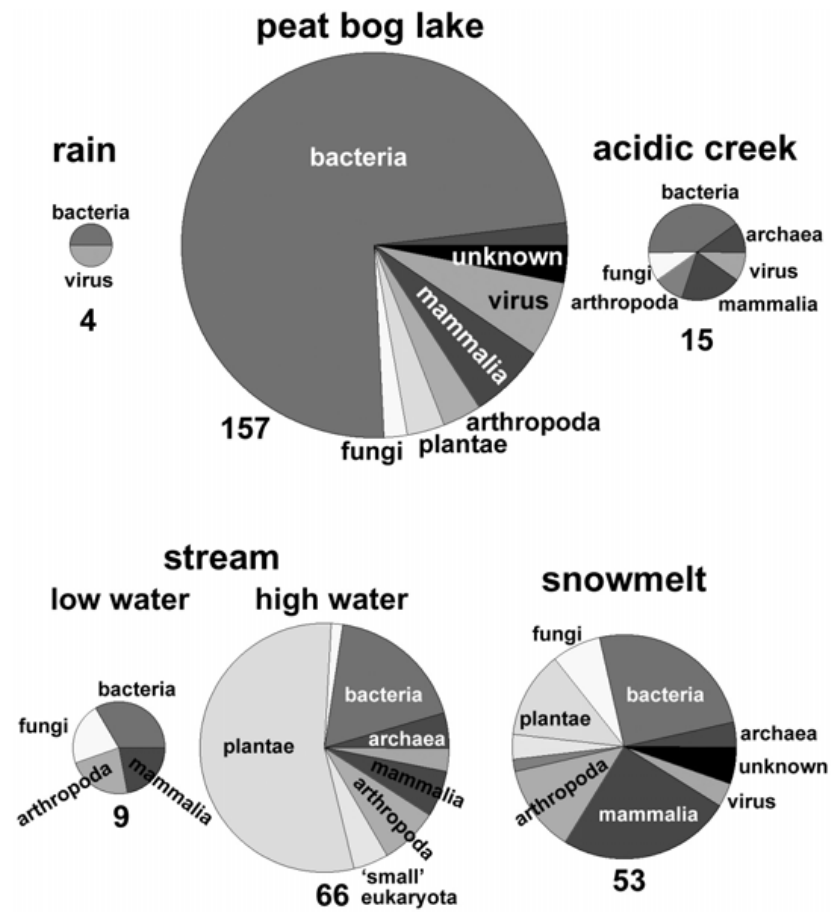

Fig. 5. Phylogenetic distribution of proteins identified in different sources of surface water, such as rain collected in a rain collector, a peat bog lake, an acidic creek in a bog area, and a stream at low and high water and water collected from snowmelt. Numbers of proteins identified are stated next to the pie charts, which are drawn in proportional size to the number of proteins.

groups. In contrast, after a summer stormflow, seven-times more proteins were detected. The soluble proteins in the DOM of the stream water at stormflow were dominated by plant proteins, and proteins from a total of eight other phylogenetic groups were identified. The observed increase in protein abundance was accompanied by an increase in DOC from $16.9 \mathrm{mgC} \mathrm{L}^{-1}$ at low flow levels to $23.3 \mathrm{mgC} \mathrm{L}^{-1}$ at the intense stormflow. In general, in samples with high DOC content (Table 1) more proteins were identified. These examples show that there is a strong variation in the phylogenetic origin of proteins as well as total number of proteins contributing to DOM of different surface waters at different seasons.

\subsection{Protein origin in DOM of soil leachates}

Total protein content of the different soil types was highest in the arenosol, whereas lowest protein amounts were found in leachates of the dystric cambisol of sub-monatane central European spruce forest and the histosol of a Sphagnum bog (Fig. 6A). Bacterial proteins made up the highest fraction in all investigated soil leachates and reached $80 \%$ in leachates of the arenosol. In the other soil leachates, the fraction of bacterial proteins ranged from $30 \%$ to $45 \%$. In leachates of cambisol and dystric cambisol a significant fraction of pro- 
teins originated from fungi and plants. Nematodal proteins were only found in leachates of temperate forests. Thus, the total protein content and taxonomic distribution of protein in DOM of soil leachates varies depending on climatic region and soil type. In addition, seasonal variations have previously been described (Schulze et al., 2005).

Bacterial proteins were analyzed in more detail for the samples of the pine forest (arenosol) and beech forest (cambisol) by distinguishing the bacterial taxonomic classes proteobacteria, actinobacteria, firmicutes, cyanobacteria, and "others". The results show that the leachates of the two soil types are significantly different with respect to the bacterial species contributing to the DOM protein pool (Fig. 6B). Although proteins from proteobacteria were most abundant in both environments, the beech forest soil leachate contained higher percentages of proteins from cyanobacteria and firmicutes compared to the pine forest on sandy soils. This demonstrates that the protein analysis is suitable of displaying composition of the microbial communities contributing to DOM protein also at finer taxonomic resolution (Fig. 6B), but at the same time covering information about the whole spectrum of organism groups (Fig. 6A).

3.6 From organic material to DOM: taxonomic compositions of DOM along a path through the soil

At the sampling site at Tura, Siberia, DOM samples were obtained along a path from decomposition (Fig. 4) to soil leachate and finally to stream water (Figs. 5 and 6). This system is especially suited to analyze the protein composition of DOM along this path of organic matter production and removal by sorption or degradation.

Hierarchical clustering was applied to group the proteomic fingerprints of DOM from different soil leachates and surface water run-offs (Table 1). It became apparent that the two soil leachates (from a north and south facing slope) group together, while proteomic fingerprints of snowmelt runoff and low water flow in a stream show similar patterning. The taxonomic fingerprint of a stream after a high stormflow shows a very distinct pattern, while the soil leachate at $40 \mathrm{~cm}$ depth just above permafrost groups on a separate branch from top layer soil leachates and surface runoff. While highest diversity of protein origin can be found in top layer soil leachates, this diversity is strongly reduced with increasing soil depth, and the overall protein number is also reduced. Samples with high DOC content showed higher numbers of identified proteins (Table 1).

Proteins in samples from low level surface water runoff (snowmelt, low waterflow in a stream) show a high diversity of taxonomic origin, but are distinct from soil leachates by their lower fraction of bacterial proteins. The clustering indicates that water flow through the soil and the environment is a critical factor during the generation of DOM and it influences the composition of the protein component of DOM.
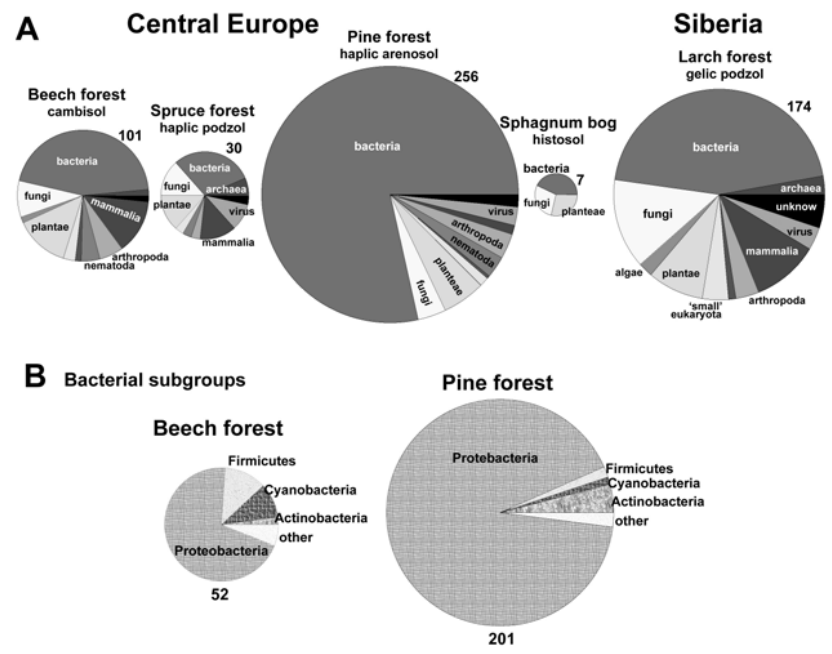

Fig. 6. (A) Phylogenetic distribution of proteins identified from DOM leachates of different soil types. (B) Detailed taxonomic view of the bacterial proteins of in DOM of the beech forest (cambisol) and pine forest (arenosol). Numbers of proteins identified are stated next to the pie charts, which are drawn in proportional size to the number of proteins.

\subsection{Reproducibility of the "proteomic fingerprint"}

The protein analysis of environmental samples will be subject to variations between sampling sites and sampling times. In order to be able to interpret the taxonomic distribution of proteins from DOM, the sample-to-sample variability was analyzed. Independent samples from a central European beech forest (cambisol, beech forest on limestone in the Hainich, Germany, see Fig. 5) were taken at the same time from three different sampling sites in a line $25 \mathrm{~m}$ apart from each other. Although $30 \%$ more proteins were detected at site 2 compared to the other two sites, the pattern of taxonomic origin of proteins showed no significant differences between sampling sites (chi-squared test), indicating that the result of the protein analysis, the identification and classification is reproducible. Also the "proteomic fingerprint" of decomposing material (Fig. 4) was reproduced from three independent samples with no significant differences in the taxonomic distribution of protein origin between them (data not shown). In addition, all taxonomic distributions presented in Figs. 4 to 6 were significantly different (chi-squared test) from a random distribution of taxonomic units as derived from the all protein entries into the NCBI-protein database. Although the result may seem surprising, as small scale heterogeneity in soils would be expected to result in small scale variations of microbial communities, the proteomic fingerprint may not resolve these variations, as they most probably occur at the species level. 


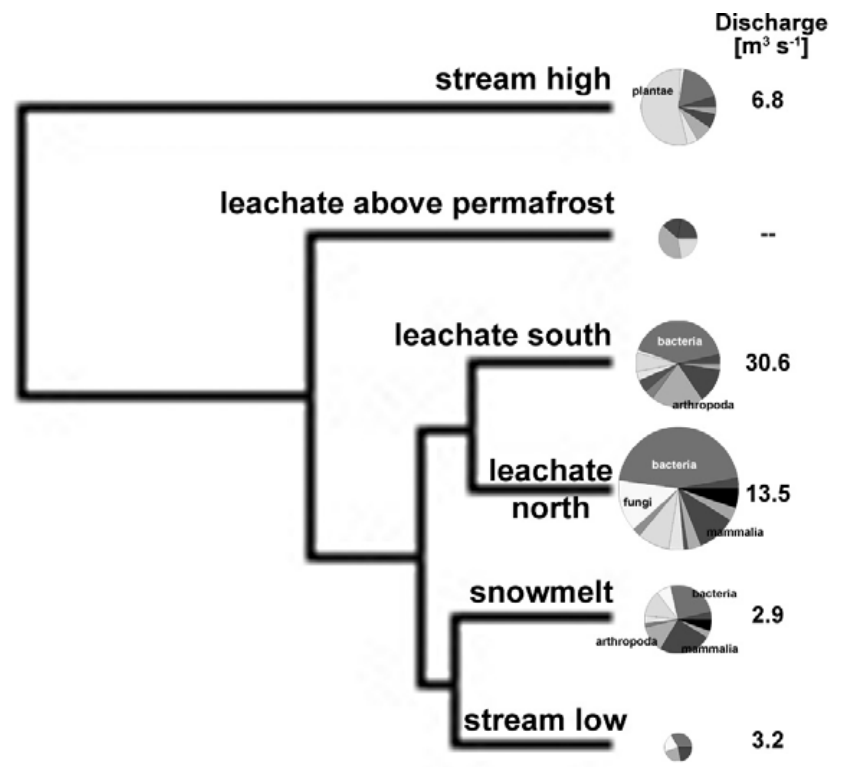

Fig. 7. Hierarchical clustering of proteomic fingerprints of DOM from different sources along the path of water through the soil. Snowmelt and stream water are surface waters, while leachates were collected at $5 \mathrm{~cm}$ and above permafrost at $40 \mathrm{~cm}$. Samples were collected at the experimental site at Tura, Siberia.

\section{Discussion}

This study focuses on a "survey" analysis of the protein component of DOM with respect to taxonomic and functional classification. Therefore, samples from regions displaying vast differences in ecosystem biology with respect to climatic region and soil type were analyzed. The protein analysis not only represents a powerful tool for taxonomic classification, but also contributes to a chemical characterization of DOM.

\subsection{Interpretation of the "proteomic fingerprint"}

Although most of the result presented here are not unexpected, the analysis of proteins at different stages of decomposing plant material (Fig. 1) is especially well suited to validate the methodology of protein detection and classification of taxonomic origin. The high fraction of bacterial proteins in protein extracts of green plant material is not surprising as bacteria are expected to be present in all environmental samples. A thorough analysis of microbial biomass suggested a ratio of bacteria to fungi of $35 \%$ to $65 \%$ in the $\mathrm{FH}$ layer of a natural beech forest (Ellenberg et al., 1986). The protein analysis revealed equal amounts of bacterial and fungal proteins in the FH layer.

However, the protein analysis is not a direct measure of biomass but rather it emphasizes the actual turnover and metabolic activity of the respective phylogenetic group. This is concluded from differences in ribosomal protein abundance in samples from different seasons. As ribosomes are essential components of the protein synthesis machinery in a cell, their abundance correlates with the metabolic or growth activity of cells (Gao et al., 1994). Therefore, low abundance of ribosomal proteins in winter DOM samples, may indicate a lower activity and turnover of bacteria in winter. Thus, the functional classification of proteins may possibly be an indicator of organism activity in a given ecosystem.

Detailed interpretation of every difference between the "proteomic fingerprints" of various water sources and soil leachates is not possible at this stage. The analysis clearly shows that each environment has its "fingerprint", which can be meaningful on a broader scale. For example the drastic increase in plant proteins in stream water after a stormflow can be interpreted by the accumulation of fresh plant material in the flood. Furthermore, the low amount of protein in the Siberian stream at low water level could indicate that in-situ geochemical processes influence the protein composition: At the Siberian sampling site, water percolates from the organic layer (shown in Fig. 4) through the mineral soil (shown in Fig. 6) until it appears in the stream (shown in Fig. 5). Along this path, plant proteins from the organic moss layer disappear and proteins from other organisms emerge (summarized in Fig. 7).

The results of the hierarchical clustering of DOM proteomic fingerprints of the Tura sampling site in Siberia suggest that water discharge affects DOM protein origin and composition, and that the pattern of protein origin changes along the path from decomposing material to stream water. The effect of discharge on DOM dynamics has already been demonstrated by using $\delta^{13} \mathrm{C}$ and $\delta^{15} \mathrm{~N}$ signatures as tracers (McTiernan et al., 1999), and the Tura watershed path of organic carbon has been reconstructed using $\delta^{13} \mathrm{C}$ signatures and DOM pyrrolysis products (Prokushkin, manuscript in preparation).

\subsection{Enzymes in DOC}

A key question remains as to whether any of the proteins with enzymatic function identified in DOM is actually functional and thus actively involved in geochemical processes. Enzyme activity tests have so far been mainly applied to characterize microbial communities, often without separating bulk soil from dissolved organic matter (Lee et al., 2004; Singh and Rai, 2004). Enzyme activities associated with particulate organic matter have been well studied (Stemmer et al., 1998; Sessitsch et al., 2001; Misic et al., 2002).

In contrast, activities of free enzymes in dissolved organic matter are rarely assessed, and focus mainly on the pollution through sewage work outlets (Chappell and Goulder, 1994). None of the enzymes identified from DOM in this study were true extracellular enzymes, but laccase protein sequences were identified by mass spectrometry as being bound to organic particles in soils, but not in free DOM (Schulze et al., 2005). Moreover, the high proportion of ribosomal proteins and membrane proteins among the identified proteins, as well 
as the protein size distribution indicate that most of the proteins in DOM are products of natural cell lysis as it occurs when cells and organisms die.

Sorption to inorganic particles may be a mechanism by which enzymes are enriched at microparticles compared to the free DOM solution. However, it yet remains unclear how these sorptive processes seem to enrich for active exoenzymes, rather than affecting all proteins in the same manner.

\subsection{Taxonomic distribution and ecosystem biology}

It becomes apparent from this study that the protein components of DOM from different ecosystems clearly differ in taxonomic composition. Since the protein size distribution in DOM is not different from that of living cells (Cagney et al., 2003), degradation and adsorption of proteins to mineral particles is assumed not to depend on protein size. Sample preparation and mass spectrometric analysis does not seem to introduce a bias for certain protein sizes. The protein size distribution observed here corresponds well with analyses of dissolved organic matter as a function of molecular weight using fluorescence spectrometry. There, protein specific fluorescence peaked around $30 \mathrm{kDa}$ (Her et al., 2003). In addition, the functional classification of DOM proteins reflects the functional distribution of proteins in cells (Fig. 3). Thus, size and functional distribution of identified proteins indicate that the protein analysis of DOM indeed provides a measure of relative abundance of proteins originating from organisms of different phylogenetic groups. This interpretation is highly supported by the analysis of protein extracts from different layers of decomposing plant material (Fig. 4), which show the expected gradual increase in bacterial and fungal protein fractions, while the fraction of plant proteins decreases.

Previous analyses of particulate proteins in Pacific surface waters by fluorescence and SDS-PAGE show higher total protein presence in water samples from productive regions (Equatorial regions, and North Pacific) compared to oligotrophic regions (Tanoue, 1996). Thus, the total protein amounts determined in this study may reflect total biological activity of the ecosystem, while the taxonomic distribution reflects the contribution of different organisms to this activity.

\section{4 "Proteomic fingerprint" and alternative approaches}

The analysis of species distribution and abundance in ecosystems has been of interest for ecologists for a long time, and remains important even today when characterizing different ecosystem communities (Ellenberg et al., 1986; Ellwood and Foster, 2004). In a thorough analysis of all animal and plant species distributions, an "inventory" of organisms was carried out in a beech forest over 20 years of investigation (Ellenberg et al., 1986). Today, phospholipid fatty acid analysis, community level physiological profiles, or analysis of fatty methyl esters are established tools to study dynamics of soil microbial communities in response to environmental changes (Priha et al., 1999; Rich et al., 2003; Steger et al., 2003; Leckie et al., 2004). PCR analysis of bacterial communities has a high resolution of species identification, but is limited to the analysis of one single taxonomic group, i.e. bacteria or fungi (Liston et al., 1996; Ritchie et al., 2000; Williamson et al., 2000; Lipson et al., 2002). The "proteomic fingerprint" method described here is a rapid and powerful approach to resolve taxonomic identity up to the genus or species level, and it represents all taxonomic units from prokaryotes to eukaryotes. In that respect it is distinct from most other approaches, which focus on specific groups of organisms but seldom obtain a global view of diversity across all taxa in the give ecosystem compartment.

Thus, the protein analysis of DOM described here is an important additional and new way of displaying contribution of different organisms to an ecosystem. The environmental protein analysis has the potential to picture the taxonomic information of the complete organismic food web, but may be biased towards emphasis of metabolically active organisms with a high cellular turnover rate (i.e. bacteria). With improving sensitivity of protein mass spectrometry, and increasing efficiency of unambiguous protein identification, an even more detailed picture will emerge in future (Aebersold and Mann, 2003; Olsen et al., 2004).

With respect to the analysis of bacterial subgroups as carried out in this study (Fig. 6B), the fraction of proteobacterial proteins is much higher expected from PLFA analyses, which mostly show a majority of gram positive bacteria (actinomycetes, streptomycetes), and not proteobacteria (see for example Santruckova et al., 2003). However, there are studies in which growth test reveal the highest fraction of bacteria being gram-negative pseudomonads (Priha et al., 1999), where gram-positive and gram-negative PFLA markers are roughly equal (as \% mol; Leckie et al., 2004), or the proportion of these functional groups varies with different environments (Hackl et al., 2004). Clearly, detailed in-parallel analyses are necessary in future, to reveal specific biases between different methods. One possible explanation of these discrepancies may be that different markers have different stability to degradation.

\subsection{Limitations of the "proteomic fingerprint"}

One limiting factor of the DOM protein analysis currently lies in the incomplete genomic sequence information from many taxonomic groups. Current efforts of sequencing DNA samples extracted from environments (Venter et al., 2004) are encouraging and will provide a basis for more accurate protein identifications and possibly will allow finer distinction of organisms in future. It could be demonstrated using an experimental dataset that cross-species protein identification by mass spectrometry successfully identifies over $80 \%$ of the proteins by sequence similarity searches, because or- 
thologue proteins share sufficient sequence identity (Habermann et al., 2004). Nevertheless, there are indications that diversity of larger taxonomic entities correlates with species diversity (Báldi, 2003), supporting that the broad taxonomic classification applied here can well represent the organismic structure of the given ecosystem contributing to the DOM pools.

The stability of protein in environments needs to be addressed experimentally in more detail in future. Currently, it is not clear, whether specific proteins are resistant to degradation due to their protein structure, as has been suggested for bacterial porin proteins (Yamada and Tanoue, 2003). The size distribution and functional protein classification obtained in this study strongly suggests that porins are frequently detected in DOM samples because they are highly abundant in the bacterial membranes, and that degradation of protein occurs at random. However, initial experiments with synthetic proteins confirm that glycosylated proteins degrade more slowly than protein or sugars alone, possibly due to their increased sorption to soil particles and thus decreased accessibility by degrading enzymes (Keil and Kirchman, 1993).

Although protein numbers and distribution of phylogenetic origin of samples taken from the same environment and soil type are non-random and reproducible, care needs to be taken when protein amounts between different soil substrates are compared (see Figs. 5 and 6). In this study, samples were analyzed based on equal mass of freeze-dried DOM. Depending on soil type and matrix, the inorganic salt content may vary and have direct impact on the mass of actual organic substance subjected to the analysis. In-depth analysis of matrix effects and sample size needs to be considered in future.

\section{Conclusions}

The method of "proteomic fingerprinting" of DOM has the potential to become a rapid approach to compare organism presence in environments and their seasonal changes. Most importantly, proteins mirror the catalytically active component of dissolved organic matter. Thus, analysis of protein identity can improve our understanding of soil organic chemistry. Although in the examples analyzed here, detection of biodegradative enzymes seems like searching a needle in the haystack, combination of mass spectrometric protein identification with immunprecipitation or affinity purifications can serve as future tools to study specific enzymes of interest.

In conclusion, despite the current limitations, mass spectrometric analysis of proteins in DOM opens a new way of describing the biological origin of this yet fairly uncharacterized component of DOM. Although the approach in this study has been applied to natural or semi-natural ecosystems, it is obvious, that the methodology may be very powerful to characterize effects of management on biological com- munities, as pioneered in a characterization of DOM protein of a healthy and girdled forest (Schulze et al., 2005). The methodology may also have a potential in identifying novel uncultured organisms which can be important in biodegradation of environmental spills.

Acknowledgements. I would like to thank G. Gleixner, K. Kaiser, K. Kalbitz, and especially A. Prokushkin for donating samples, and I am very grateful to E.-D. Schulze for critical comments on the manuscript.

Edited by: J. Kesselmeier

\section{References}

Aebersold, R. and Mann, M.: Mass spectrometry-based proteomics, Nature, 422, 198-207, 2003.

Almendros, G., Frund, R., Gonzalez-Vila, F. J., Haider, K. M., Knicker, H., and Ludemann, H. D.: Analysis of $13 \mathrm{C}$ and $15 \mathrm{~N}$ CPMAS NMR-spectra of soil organic matter and composts, FEBS Lett., 282, 119-121, 1991.

Báldi, A.: Using higher taxa as surrogates of species richness: a study based on 3700 Coleoptera, Diptera and Acri in CentralHungarian reserves, Basic and Applied Ecology, 4, 589-593, 2003.

Cagney, G., Amiri, S., Premawaraadena, T., Lindo, M., and Emili, M.: In silico proteome analysis to facilitate proteomics experiments using mass spectrometry, Proteome Science, 1, 1-15, 2003.

Chappell, K. R. and Goulder, R.: Enzymes as river pollutants and the response of native epilithic extracellular-enzyme activity, Environmental Pollution, 86, 161-169, 1994.

Ellenberg, H., Mayer, R., and Schauermann, J.: Ökosystemforschung - Ergebnisse des Sollingprojekts, Stuttgart, Ulmer Verlag, 1986.

Ellwood, M. D. F. and Foster, W. A.: Doubling the estimate of invertebrate biomass in a rainforest canopy, Nature, 429, 459-551, 2004.

Gao, J., Kim, S.-R., Chung, Y.-Y., Lee, J. M., and An, G.: Developmental and environmental regulation of two ribosomal protein genes in tobacco, Plant Mol. Biol., 25, 761-770, 1994.

Gleixner, G., Czimczik, C., Kramer, C., Lühker, B., and Schmidt, M. W. I.: Plant compounds and their turnover and stability as soil orgainc matter, In: Global Biogeochemical cycles in the climate system, edited by: Schulze, E. D., Heimann, M., Harrison, S., Holland, E., Lloyd, L., Prentice, I. C., and Schimel, D., San Diego, Academic Press, 201-216, 2001.

Habermann, B., Oegerma, J., Sunyaev, S., and Shevchenko, A.: The power and the limitations of cross-species protein identification by mass spectrometry-driven sequence similarity searches, Mol. Cell. Proteomics, 3, 238-249, 2004.

Her, N., Amy, G., McKnight, D., Sohn, J., and Yoon, Y.: Characterization of DOM as a function of MW by fluorescence EEM and HPLC-SEC using UVA, DOC, and fluorescence detection, Water Research, 2003, 17, 4295-4303, 2003.

Ishihama, Y., Rappsilber, J., Andersen, J. S., and Mann, M.: Microcolumns with self-assembled particle frits for proteomics, J. Chromatogr. A, 979, 233-239, 2002. 
Kaiser, K., Guggenberger, G., Haumaer, L., and Zech, W.: Seasonal variations in the chemical composition of dissolved organic matter in organic forest floor layer leachates of old-growth Scots pine (Pinus sylvestris L.) and European beech (Fags sylvatica L.) stands in northeastern Bavaria, Germany, Biogeochem., 55, 103143, 2001.

Keil, R. and Kirchman, D. L.: Dissolved combined amino acids: Chemical form and utilization by marine bacteria, Limnology and Oceanography, 38, 1256-1270, 1993.

Kracht, O. and Gleixner, G.: Isotope analysis of pyrolysis products from Sphagnum peat and dissolved organic matter from bog water, Organic Geochemistry, 31, 645-654, 2000.

Leckie, S. E., Prescott, C. E., Grayston, S. J., Neufeld, J. D., and Mohn, W. W.: Characterization of humus microbial communities in adjacent forest types that differ in nitrogen availability, Microb. Ecol., 48, 29-40, 2004.

Lee, J. J., Park, R. D., Kim, Y. W., Shim, J. H., Chae, D. H., Rim, Y. S., Sohn, B. K., Kim, T. H., and Kim, K. Y.: Effect of food waste compost on microbial population, soil enzyme activity and lettuce growth, Bioresour. Technol., 93, 21-28, 2004.

Lipson, D. A., Schadt, C. W., and Schmidt, S. K.: Changes in soil microbial community structure and function in an alpine dry meadow following spring snow melt, Microb. Ecol., 43, 307314, 2002.

Liston, A., Robinson, W. A., and Oliphant, J. M.: Length variation in the nuclear ribosomal DNA internal transcribed spacer region of non-flowering seed plants, Syst. Bot., 21, 109-120, 1996.

Lu, J., Sanchez, S., Hofacre, C., Maurer, J. J., Harmon, G. B., and Lee, M. D.: Evaluation of broiler litter with reference to the microbial composition as assessed by using $16 \mathrm{~S}$ rRNA and functional gene markers, Apppl. Environ. Microbiol., 62, 901-908, 2003.

Michalzik, B. and Matzner, E.: Dynamics of dissolved organic nitrogen and carbon in a Central European Norway spruce ecosystem, Eur. J. Soil Sci., 50, 579-590, 1999.

Misic, C., Povero, P., and Fabiano, M.: Ectoenzymatic ratios in relation to particulate organic matter distribution (Ross Sea, Antarctica), Microb. Ecol., 44, 224-234, 2002.

Olsen, J. V., Ong, S.-E., and Mann, M.: Trypsin cleaves exclusively C-terminal to arginine and lysine residues, Mol. Cell. Proteomics, 3, 608-614, 2004.

Perkins, D. N., Pappin, D. J. C., Creasy, D. M., and Cottrell, J. S.: Probability-based protein identification by searching sequence databases using mass spectrometry data, Electrophoresis, 20, 3551-3567, 1999.

Priha, O., Grayston, S. J., Pennanen, T., and Smolander, A.: Microbial activities related to $\mathrm{C}$ and $\mathrm{N}$ cycling and microbial community structure in the rhizospheres of Pinus sylvestris, Picea abies and Betula pendula seedlings in an organic and mineral soil, FEMS Microbiol. Lett., 30, 187-199, 1999.

Rappsilber, J. and Mann, M.: What does it mean to identify a protein in proteomics, Trends Biochem. Sci., 27, 74-78, 2002.

Rappsilber, J., Ryder, U., Lamon, A. I., and Mann, M.: Large-scale proteomic analysis of the human spliceosome, Genome Res., 12, 1231-1245, 2002.

Rappsilber, J., Ishihama, Y., and Mann, M.: Stop and go extraction tips for matrix-ssisted laser desorption/ionization, nanoelectrospray, and LC/MS sample pretreatment in proteomics, Anal. Chem., 75, 663-670, 2003.
Rich, J. J., Heichen, R. S., Bottomley, P. J., Cromack, K., and Myrold, D. D.: Community composition and functioning of denitrifying bacteria from adjacent meadow and forest soils, Apppl. Environ. Microbiol., 69, 5974-5982, 2003.

Ritchie, N. J., Schutter, M. E., Dick, R. P., and Myrold, D. D.: Use of length heterogeneity PCR and fatty acid methyl ester profiles to characterize microbial communities in soil, Apppl. Environ. Microbiol., 66, 1668-1675, 2000.

Roepstorff, P. and Fohlman, J.: Proposal for a common nomenclature for sequence ions in mass spectra of peptides, Biomed. Mass Spectrom., 11, 601, 1984.

Schulze, W., Gleixner, G., Kaiser, K., Guggenberger, G., Mann, M., and Schulze, E. D.: A proteomic fingerprint of dissolved organic carbon and soil particles, Oecologia, 142, 335-343, 2005.

Sessitsch, A., Weilharter, A., Gerzabek, M. H., Kirchmann, H., and Kandeler, E.: Microbial population structures in soil particle size fractions of a long-term fertilizer field experiment, Apppl. Environ. Microbiol., 67, 4215-4224, 2001.

Shevchenko, A., Wilm, M., Vorm, O., and Mann, M.: Mass spectrometric sequencing of proteins silver-stained polyacrylamide gels, Anal. Chem., 68, 850-858, 1996.

Shevchenko, A., Sunyaev, S., Loboda, A., Shevchenko, A., Bork, P., Ens, W., and Standing, K. G.: Charting the proteomes of organisms with unsequenced genomes by MALDI-quadrupole time-of-flight mass spectrometry and BLAST homology searching, Anal. Chem., 73, 1917-1926, 2001.

Singh, S. K. and Rai, J. P.: Soil microbial population and enzyme activity related to grazing pressure in alpine meadows of Nanda Devi Biosphere Reserve, J. Environ. Biol., 25, 103-107, 2004.

Steger, K., Jarvis, A., Smars, S., and Sundh, I.: Comparison of signaturelipid methods to determine microbial community structure in compost, J. Microbiol. Meth., 55, 371-382, 2003.

Stemmer, M., Gerzabek, M. H., and Kandeler, E.: Organc matter and enzyme activity in particle-size fractions of soils obtained after low-energy sonication, Soil Biol. Biochem., 30, 9-17, 1998.

Suzuki, S., Kogure, K., and Tanoue, E.: Immunochemical detection of dissolved proteins and their source bacteria in marine environments, Marine Ecology Progress Series, 158, 1-9, 1997.

Tanoue, E.: Characterization of the particulate protein in Pacific surface waters, J. Marine Res., 54, 967-990, 1996.

Tanoue, E., Ishii, M., and Midorikawa, T.: Discrete dissolved and particulate proteins in oceanic waters, Limnology and Oceanography, 41, 1334-1343, 1996.

The Arabidopsis Genome Initiative: Analysis of the genome sequence of the flowering plant Arabidopsis thaliana, Nature, 408, 796-816, 2000.

Tyers, M. and Mann, M.: From genomics to proteomics, Nature, 422, 193-197, 2003.

Tyson, G. W., Chapman, J., Hugenholtz, P., Allen, E. E., Ram, R. J., Richardson, P. M., Solovyev, V. V., Rubin, E. M., Rokhsar, D. S., and Banfield, J. F.: Community structure and metabolism through reconstruction of microbial genomes from the environment, Nature, 428, 37-43, 2004.

Venter, J. C., Remington, K., Heidelberg, J. F., Halpern, A. L., Rusch, D. B., Eisen, J. A., Wu, D., Paulsen, I., Nelson, K. E., Nelson, W., Fouts, D. E., Levy, S., Knap, A. H., Lomas, M. W., Nealson, K., White, O., Peterson, J., Hoffman, J., Parson, R., Baden-Tillson, H., Pfannkoch, C., Rogers, Y.-H., and Smith, H. O.: Environmental genome shotgun sequencing of the Sargasso 
Sea, Science, 304, 66-74, 2004.

Williamson, N., Biran, P., and Wellington, E. M.: Molecular detection of bacterial and streptomycete chitinases in the environment, Antonie Van Leeuwenhook, 78, 315-321, 2000.

Wilmes, P. and Bond, P. L.: The application of two-dimensional polyacrylamide gel electrophoresis and downstream analyses to a mixed community fo prokaryotic microorganisms, Env. Microbiol., 6, 911-920, 2004.
Yamada, N. and Tanoue, E.: Detection and partial characterization of dissolved glycoproteins in oceanic waters, Limnology and Oceanography, 48, 1037-1048, 2003. 